\title{
Pengenalan Bisnis Kopi Kayu Manis kepada Mahasiswa Akademi Komunitas Presiden
}

\author{
Abdul Ghofir ${ }^{1)}$, Genta Sahuri²), Dedi Rianto Rahadi3) \\ 1) Faculty of Computing, President University,geoff@president.ac.id \\ 2) Faculty of Computing, President University, genta.sahuri@president.ac.id \\ 3) Faculty of Business, President University, dediriantorahadi@president.ac.id
}

\begin{abstract}
ABSTRAK
Bagi sebagian masyarakat baik pria maupun wanita, kopi merupakan minuman wajib setiap hari. Utamanya adalah di pagi hari jelang beraktifitas, maupun pada jam-jam sibuk kerja. Kopi adalah ibarat teman yang selalu setia menemani dalam kondisi apapun. Tren kopi yang semakin meningkat membuat bisnis kopi kian merebak. Berbagai cara orang melakukan bisnis kopi. Mulai dari bisnis yang sederhana seperti pedagang kaki lima hingga restoran berbintang. Persaingan yang tinggi membuat para pebisnis kopi harus pandai berinovasi. Berbekal dari kemampuan meracik kopi, kemudian sejumlah mahasiswa dan dosen Jurusan Manajemen President University membuat sebuah gagasan untuk meracik kopi dengan kayu manis. Racikan kopi kayu manis ini dikemas secara sederhana dalam sebuah botol plastik kecil berukuran $250 \mathrm{ml}$, yang kemudian dijual dengan harga yang sangat terjangkau baik online maupun offline. Kemampuan meracik dan berbisnis kopi kayu manis ini kemudian ditularkan kepada masyarakat lain yaitu Mahasiswa Akademi Komunitas Presiden. Prinsipnya adalah berbagi, berbagi pengetahuan, berbagi pengalaman, dan berbagi ceria.
\end{abstract}

Kata-kata Kunci: Kopi, Kayu Manis, Bisnis, Industri.

\section{ABSTRACK}

Coffee is a mandatory drink for some people, both man and woman. It is very delicious to be enjoyed, especially in the morning before the move, or during rush hours at work. Coffee is like a friend whose always present in any condition. Increasing coffee trends make the coffee business increasingly widespread. Many ways have been done by people to do coffee business. Ranging from simple coffee business such as street vendors to starred restaurant. High competition makes the coffee business must be good in innovating. Armed with the ability to mix coffee, then a number of students and lecturers of President University Majoring in Management made an idea to mix coffee with cinnamon. The concoction of cinnamon coffee is simply packaged $250 \mathrm{ml}$ plastic bottle, which is then sold at very affordable prices both online and offline. The ability to mix and do cinnamon coffee business is then transmitted to other communities, that is the students of Akademi Komunitas Presiden. The principle is sharing, sharing knowledge, sharing experience, and sharing cheerful.

Keywords: Coffee, Cinnamon, Business, Industry.

\section{PENDAHULUAN}

Kopi kayu manis adalah minuman berkhasiat yang terdiri dari kopi dan kulit kayu manis yang mengandung antioksidan sehingga baik untuk kesehatan. Rasanya sangat nikmat, khas dan beraroma wangi. Minuman ini sangat cocok dikonsumsi kapan aja, baik dengan sajian panas maupun dingin.

Kopi adalah salah satu jenis tanaman perkebunan yang mempunyai nilai ekonomis tinggi. Dilihat dari sisi pengkonsumsinya di seluruh dunia, kopi arabika adalah kopi yang memiliki tingkat konsumsi tertinggi yaitu mencapai 70\%. Selanjutnya adalah kopi robusta, yaitu $26 \%$. Kopi itu sendiri awalnya adalah berasal dari sebuah pegunungan di Etiopia, Afrika. Kemudian kopi mulai dikenal oleh masyarakat secara luas setelah di pasarkan oleh 
seorang saudagar dari Arab di Yaman, atau di bagian selatan Jazirah Arab (Rahardjo, 2012). Di Indonesia, kopi mulai dikenal pada tahun 1696 yang diperkenalkan oleh para kolonial Belanda atau VOC (Najiyati, 1997).

Kopi adalah kategori tanaman semak belukar (genus coffea), yang masuk dalam famili Rubiceae, dengan sub-famili Ixorodeae, dan suku coffeae. Linnaeus adalah orang yang pertama kali mendiskripsikan spesies kopi (Coffea Arabica) pada tahun 1753 (Panggabean, 2011a; Panggabean, 2011b).

Kopi merupakan jenis tanaman tropis. la juga merupakan minuman yang mengandung kafein. Banyak manfaat yang di dapat apabila mengkonsumsi kopi. Antara lain, kafein yang terkandung di dalamnya dapat meningkatkan laju metabolisme tubuh. Bagi mereka yang memiliki rutinitas di malam hari, kopi adalah minuman alternatif yang baik karena kandungan kafein didalamnya dapat mengurangi rasa kantuk. Selain itu, kopi juga memiliki sifat anti bakteri yang baik sehingga dapat menyembuhkan berbagai masalah yang berkaitan dengan kesehatan.

Ada 2 jenis kopi yang dikenal di masyarakat, yaitu kopi arabika dan kopi robusta. Kadar kafein kedua kopi tersebut berbeda. Kopi robusta memilki kadar kafein yang lebih tinggi dari pada kopi arabika. Di Indonesia, kopi dijual secara bebas. Ada yang dijual dalam bentuk biji kopi, sangrai, bubuk, kopi instan, maupun yang dicampur dengan bahan makanan atau minuman lain (Kartika, Rifin, \& Saptono, 2018).

Kayu manis adalah tanaman rempah-rempah yang kulit, batang, dan dahannya mempunyai khasiat sebagai obat-obatan. la merupakan komoditas ekspor Indonesia. Khasiatnya yang penting bagi tubuh manusia membuat kayu manis banyak dijadikan sebagai bahan campuran makanan atau minuman olahan dan bumbu masak tradisional. Kulit kayu manis mempunyai rasa dan aroma yang khas dan bermafaat baik bagi kesehatan seperti ramuan pencegah penyakit gula (Ferry, 2013).

Kopi dan kayu manis memiliki antioksidan. Kandungan anti oksidan pada kopi mampu mencegah kerusakan sel-sel otak, serta baik untuk kesehatan hati. Kulit kayu manis kering (cassiavera) mengandung sinamaldehid, eugenol, dan senyawa lain seperti flavonoid, tannin, triterpenoid, dan saponin. Diantara senyawa tersebut ada yang berfungsi sebagai antioksidan di dalam tubuh (Widiyanto, Anandito, \& Khasanah, 2013).

Proses penyeduhan pada minuman kopi dapat dilihat dar perbedaan suhu dan waktu penyeduhan. Proses pembuatan minuman kopi biasanya pada suhu sekitar $90-100^{\circ} \mathrm{C}$ dengan waktu \pm 3 menit. Prinsip proses penyeduhan adalah menuangkan air mendidih ke dalam bubuk kopi dan merendam bubuk kopi di dalam air panas untuk mengekstrak kandungan bubuk kopi. Kopi harus ditunggu beberapa saat hingga ampas kopi mengendap seluruhnya, sebelum kopi tersebut diminum. Seduhan kopi juga dapat dibuat dengan cara 
memanaskan air beserta bubuk kopi hingga mendidih. Cara ini sering digunakan untuk menimbulkan warna serta rasa kopi panas yang sesuai selera konsumen.

Berbekal dari pengetahuan antara dua tanaman itulah kemudian dilakukan suatu percobaan dengan mengkombinasikan kedua bahan tersebut dalam sebuah minuman, yang kemudian disebut kopi kayu manis. Penambahan kulit kayu manis pada pada kopi diharapkan dapat memperbaiki karakteristik mutu bubuk kopi yang dihasilkan dan cara penyeduhan yang juga memperngaruhi aroma dan rasa seduhan kopi yang dihasilkan.

Di era sekarang ini, kesehatan sangatlah mahal. Banyak masyarakat yang terkena penyakit akibat terlalu sering mengkonsumsi minuman cepat saji dan mengandung alkohol. Berdasarkan kondisi ini, kemudian muncul ide untuk membuat minuman kopi sehat dengan penambahan kayu manis yang mengandung herbal dan aman untuk dikonsumsi.

Keberhasilan mengkombinasi kopi dan kayu manis tersebut menimbulkan inisiatif untuk membuat produk minuman kopi kayu manis yang diperjualbelikan kepada masyarakat secara luas. Dan ide kreatif ini kemudian diperkenalkan kepada masyarakat lain, khususnya mereka yang masih duduk di bangku kulliah, yaitu Mahasiswa Akademi Komunitas Presiden.

\section{METODE PELAKSANAAN}

Tahapan yang dilaksanakan untuk mempresentasikan bisnis kopi kayu manis kepada Mahasiswa Akademi Komunitas Presiden adalah:
a. Presentasi materi
b. Demonstrasi pembuatan kopi kayu manis
c. Peserta berlatih meracik kopi kayu manis
d. Menikmati hasil pembuatan kopi kayu manis

Acara tersebut dilaksanakan pada hari Jum'at, 6 Desember 2019 di sebuah cafe di Cikarang Baru, yang diikuti oleh Mahasiswa Akademi Komunitas Presiden. Antusiasme dan keceriaan terlihat pada wajah mereka dalam mengikuti acara ini, seperti ditunjukkan pada Gambar 1. 


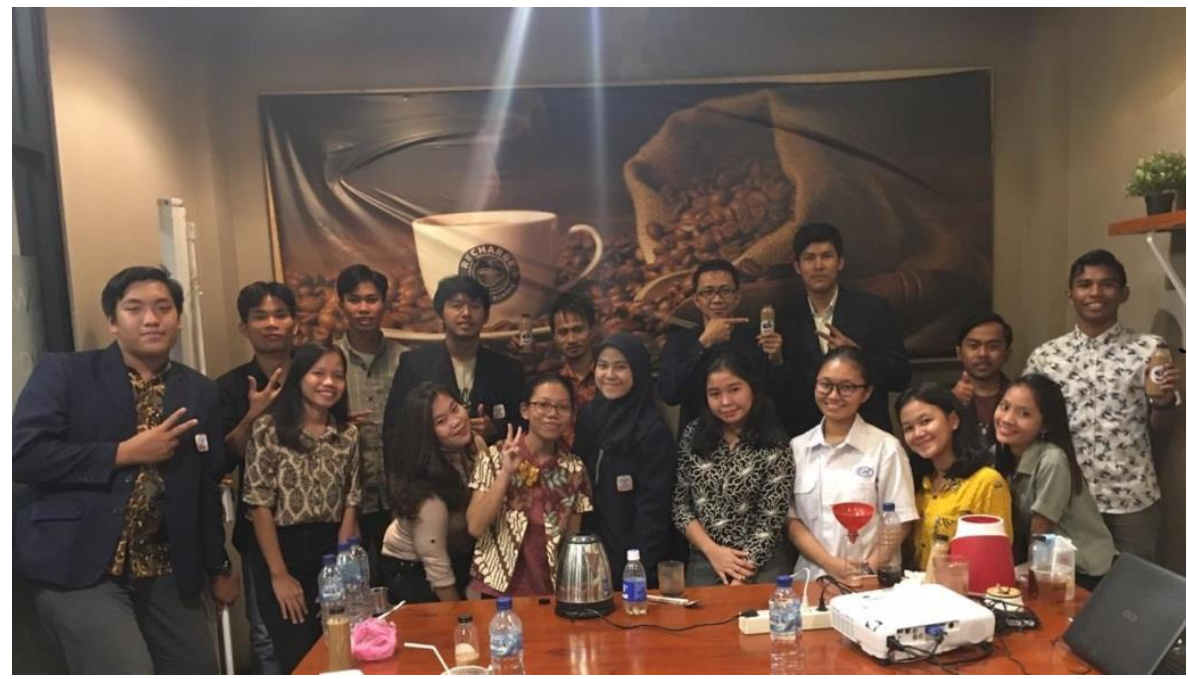

Gambar 1.

Instruktur dan Peserta Pengenalan Bisnis Kopi Kayu Manis

\subsection{Presentasi Materi}

Dalam mempresentasikan materi, instruktur yang terdiri dari lima mahasiswa Program Studi Manajemen President University memaparkan teori-teori tentang kopi, kayu manis, bahan-bahan yang diperlukan, cara meracik hingga perhitungan komposisinya secara detail dan bergantian. Bahan-bahan kopi kayu manis ditampilkan pada Tabel 1.

Tabel 1.

Bahan-bahan Kopi Kayu Manis

\begin{tabular}{|c|l|l|}
\hline No. & \multicolumn{1}{|c|}{ Nama bahan } & \multicolumn{1}{|c|}{ Kuantitas } \\
\hline 1 & Biji kopi & $120 \mathrm{gr}$ \\
\hline 2 & Susu segar & $1000 \mathrm{ml}$ \\
\hline 3 & Gula & $1000 \mathrm{gr}$ \\
\hline 4 & Kayu manis & $10 \mathrm{batang}$ \\
\hline 5 & Expresso & $1000 \mathrm{ml}$ \\
\hline
\end{tabular}

Selain bahan-bahan di atas, diperlukan pula peralatan penunjang dalam proses peracikan kopi kayu manis hingga pengemasan. Peralatan tersebut terlihat pada Tabel 2.

Tabel 2.

Peralatan untuk Meracik dan Mengemas Kopi Kayu Manis

\begin{tabular}{|c|l|l|}
\hline No. & \multicolumn{1}{|c|}{ Jenis Peralatan } & \multicolumn{1}{|c|}{ Satuan } \\
\hline 1 & Blender & 1 unit \\
\hline 2 & Saringan Kopi & 1 unit \\
\hline 3 & Timbangan Digital & 1 unit \\
\hline 4 & Botol Plastik $250 \mathrm{ml}$ & 15 buah \\
\hline 5 & Stiker & 15 buah \\
\hline
\end{tabular}




\subsection{Demonstrasi Pembuatan Kopi Kayu Manis}

Demonstrasi diawali dengan penyampaian materi tentang kopi kayu manis, penjelasan atas proses pengolahannya dan bahan-bahan yang diperlukan. Selanjutnya adalah mencontohkan cara meracik kopi kayu manis secara langsung di hadapan peserta seperti terlihat pada Gambar 2. Peserta nampak sangat serius memperhatikan langkah demi langkah seperti yang terlihat pada Gambar 3.

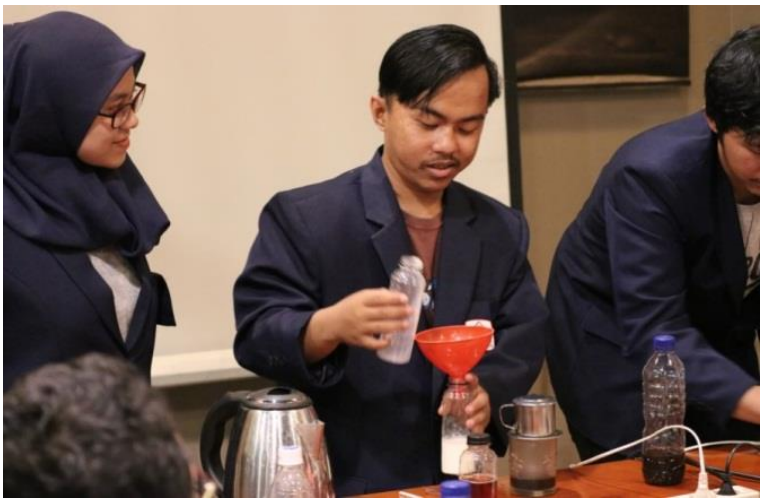

Gambar 2.

Demonstrasi oleh Instruktur tentang Meracik Kopi Kayu Manis



Gambar 3.

Peserta Demonstrasi Pembuatan Kopi Kayu Manis

Instruktur menjelaskan secara detail langkah demi langkah, sekaligus menjelaskan pula takaran atau ukuran bahan yang diperlukan agar menghasilkan hasil racikan kopi kayu manis yang nikmat. Takaran atau ukuran bahan tersebut dipaparkan pada Tabel 3. Tabel tersebut merupakan rincian bahan-bahan yang diperlukan untuk 10 botol kopi kayu manis berukuran $250 \mathrm{ml}$.

Tabel 3.

Takaran Bahan Kopi Kayu Manis, 2500 ML

\begin{tabular}{|c|l|l|}
\hline No. & \multicolumn{1}{|c|}{ Nama Bahan } & \multicolumn{1}{|c|}{ Takaran } \\
\hline 1 & Biji kopi & $100 \mathrm{gr}$ \\
\hline 2 & Susu segar & $700 \mathrm{ml}$ \\
\hline 3 & Gula & $367 \mathrm{gr}$ \\
\hline 4 & Air gula & $400 \mathrm{ml}$ \\
\hline 5 & Kayu manis & 4 batang \\
\hline 6 & Air kayu manis & $600 \mathrm{ml}$ \\
\hline 7 & Expresso & $300 \mathrm{ml}$ \\
\hline 8 & Botol plastic $250 \mathrm{ml}$ & $10 \mathrm{pcs}$ \\
\hline 9 & Sticker & $10 \mathrm{pcs}$ \\
\hline
\end{tabular}

Biji kopi ditakar sebanyak $100 \mathrm{gr}$, dihaluskan dengan blender. kemudian dilarutkan gula sebanyak 367 gram ke dalam air sebanyak $400 \mathrm{ml}$. Selanjutnya adalah kayu manis 
sebanyak 4 batang yang dihaluskan dan dicampur dengan air hingga menghasilkan $600 \mathrm{ml}$. Expresso sebanyak $300 \mathrm{ml}$ dan susu segar $700 \mathrm{ml}$ dicampurkan dengan air kopi yang sebelumnya telah diberi air panas $500 \mathrm{ml}$ dan disaring. Hasil pengolahan tersebut menghasilkan kopi kayu manis sebanyak $2500 \mathrm{ml}$, yang kemudian dikemas ke dalam 10 botol berukuran $250 \mathrm{ml}$.

\subsection{Peserta Berlatih Meracik Kopi Kayu Manis}

Sesi berikutnya adalah memberi kesempatan kepada peserta untuk mempraktikkan secara langsung bagaimana meracik kopi kayu manis. Hal ini sangat penting, karena dengan latihan membuat belajar menjadi lebih sempurna. Peserta tampak lebih bersemangat dalam sesi ini, karena mereka dapat berlatih secara langsung dengan instruktur, sebagaimana tampak pada Gambar 4.

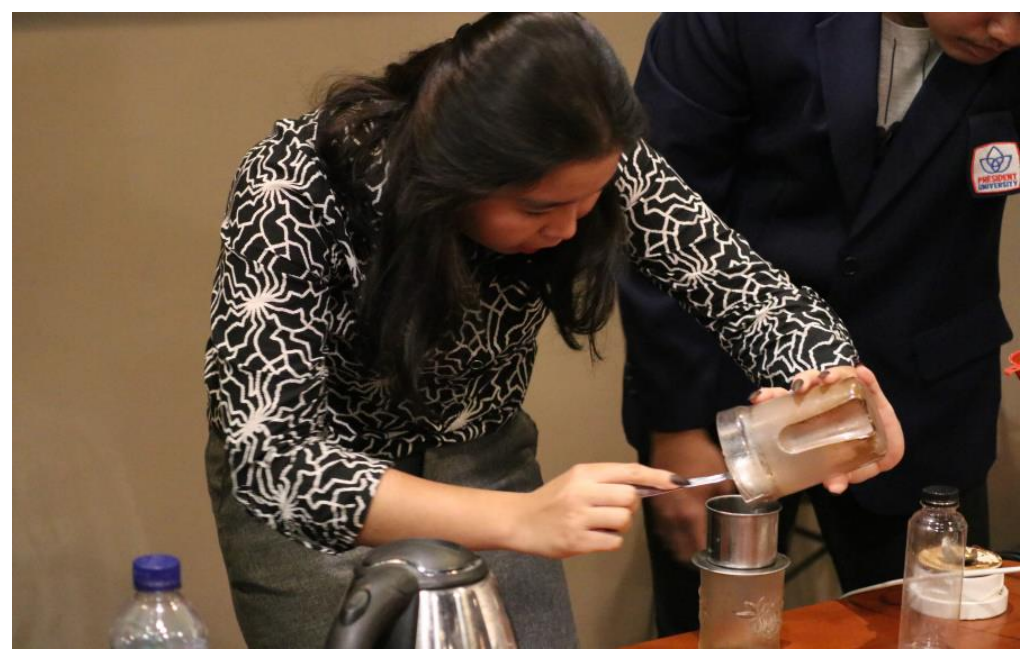

Gambar 4.

Peserta Membuat Kopi Kayu Manis

\subsection{Menikmati Kopi Kayu Manis}

Setelah tiga sesi sebelumnya terlaksana, berikutnya adalah menikmati hasil pembuatan kopi kayu manis itu sendiri. Sesi ini menjadi sesi terkhir dan yang paling ditunggu-tunggu (Gambar 5). Peserta tidak hanya menikmati minuman kopi kayu manis, namun juga menikmati hidangan makanan lainnya sebagai pendamping kopi kayu manis. Suasana pun menjadi sangat menyenangkan. Instruktur dan peserta menjadi semakin akrab, dan diskusi tentang menjadikannya sebuah bisnis dapat dimulai. 


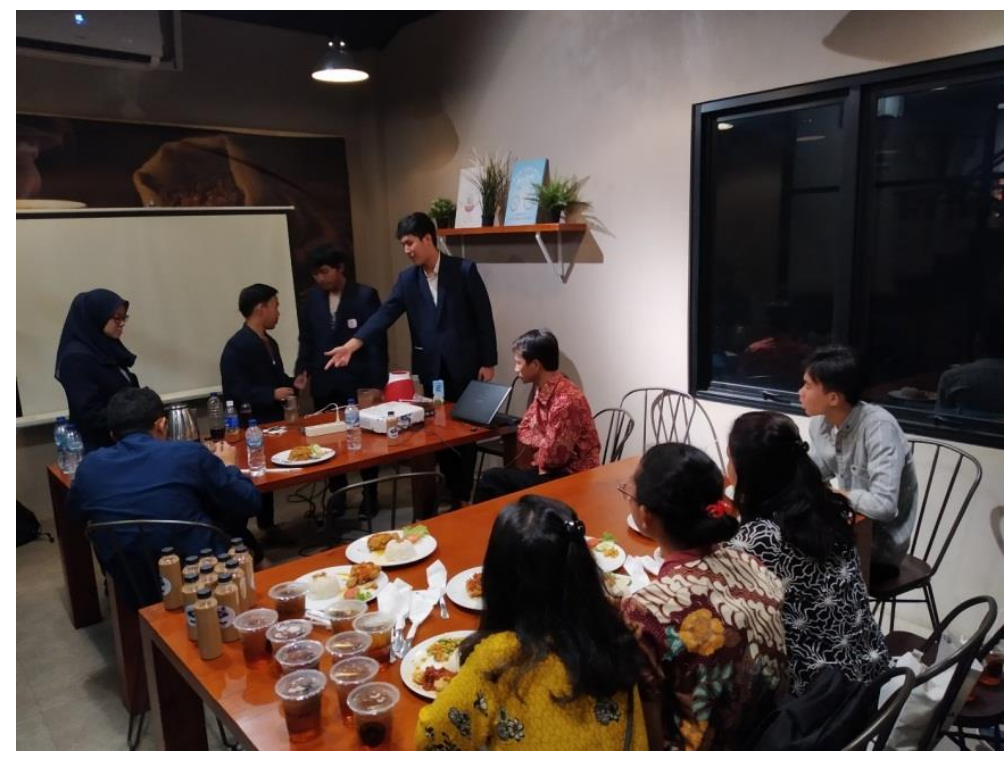

Gambar 5.

Suasana Menikmati Kopi Kayu Manis Hasil Racikan Peserta

\section{HASIL DAN PEMBAHASAN}

Dari hasil pembuatan kopi kayu manis seperti yang telah diuraikan di atas, dapat diperhitungkan biaya yang harus dikeluarkan mulai dari modal awal, biaya produksi harga jual, keuntungan dan seterusnya. Sebagai modal awal, pertama tentu harus menyediakan peralatan sebagai alat operasional produksi seperti pada Tabel 4. Modal awal untuk membeli alat peracik ini adalah sebesar Rp. 720.000,-.

Tabel 4.

Peralatan untuk Membuat Kopi Kayu Manis

\begin{tabular}{|l|l|c|}
\hline No. & \multicolumn{1}{|c|}{ Nama Alat } & Harga (Rp) \\
\hline 1 & Blender & 400.000 \\
\hline 2 & Saringan Kopi & 70.000 \\
\hline 3 & Timbangan Digital & 250.000 \\
\hline \multicolumn{2}{|c|}{ Jumlah } & 720.000 \\
\hline
\end{tabular}

Selanjutnya adalah menghitung dana yang diperlukan untuk membuat 1 botol kopi kayu manis berukuran $250 \mathrm{ml}$. Sesuai dengan perhitungan pada Tabel 5, harga pokok satu botol kopi kayu manis ukuran $250 \mathrm{ml}$ adalah sebesar Rp. 6.607. 
Tabel 5.

Penghitungan Biaya Produksi

\begin{tabular}{|l|l|l|l|l|c|c|}
\hline No & \multicolumn{1}{|c|}{ Bahan } & \multicolumn{1}{|c|}{$\begin{array}{c}\text { Qty } \\
(\mathrm{a})\end{array}$} & $\begin{array}{c}\text { Harga } \\
(\mathrm{b})\end{array}$ & $\begin{array}{c}\text { Penggunaan } \\
\text { per 10 botol } \\
(\mathrm{c})\end{array}$ & $\begin{array}{c}\text { Harga per } \\
\text { satuan } \\
(\mathrm{d})=(\mathrm{b}) /(\mathrm{a})\end{array}$ & $\begin{array}{c}\text { Total harga } \\
(\mathrm{d}) \mathrm{x}(\mathrm{c}) \\
10\end{array}$ \\
\hline 1 & Biji kopi & $120 \mathrm{gr}$ & 40.000 & $100 \mathrm{gr}$ & 333 & 3.333 \\
\hline 2 & Susu segar & $1000 \mathrm{gr}$ & 16.000 & $700 \mathrm{ml}$ & 16 & 1.120 \\
\hline 3 & Gula & $1000 \mathrm{gr}$ & 11.000 & $367 \mathrm{gr}$ & 11 & 404 \\
\hline 4 & Kayu manis & $15 \mathrm{pcs}$ & 9.000 & $4 \mathrm{pcs}$ & 600 & 240 \\
\hline 5 & Expresso & $1000 \mathrm{ml}$ & 7.000 & $300 \mathrm{ml}$ & 7 & 210 \\
\hline 6 & Botol & 15 & 19.500 & $10 \mathrm{pcs}$ & 1.300 & 1.300 \\
\hline \multicolumn{7}{|c|}{ Harga Pokok per Botol } \\
\hline
\end{tabular}

Apabila kopi kayu manis ini dijual dengan harga Rp. 10.000, maka keuntungan yang diperoleh adalah:

Rp. $10.000-$ Rp. $6.607=$ Rp. $3.393 /$ botol

Jika dalam satu hari dapat diproduksi 100 botol, maka potensi keuntungan yang diperoleh adalah:

Rp. $3.393 \times 100$ botol $=$ Rp. 339.300 .

Perhitungan di atas adalah perhitungan sederhana, dimana dalam sekali produksi yang menghasilkan 10 botol masih menyisakan bahan baku seperti biji kopi, gula, kayu manis, expresso hingga botol. Artinya, keuntungan akan lebih besar apabila kopi kayu manis bisa diproduksi secara masal, dengan jumlah produksi yang lebih besar.

\section{KESIMPULAN}

Bisnis kopi kayu manis adalah bisnis yang cukup sederhana, ringan dan menguntungkan. Bisnis ini sangat cocok untuk dikerjakan oleh paara kawula muda, khususnya mahasiswa. Modal yang tidak terlalu besar, proses pembuatan yang mudah dan pasar yang luas adalah membuat bisnis kopi kayu manis ini cukup menjanjikan. Terlebih, kopi kayu manis masih sangat jarang ditemukan. Peluang inilah yang membuat kesempatan menjadi semakin lebar, sebagai inovasi baru bagi para pecinta kopi.

Proses produksi kopi kayu manis yang sederhana telah di implementasikan, dengan perhitungan bisnis yang sangat sederhana dan jelas. Selanjutnya adalah mencari cara bagaimana untuk memasarkan kopi kayu manis ini agar lebih dikenal secara luas sehingga bisnis semakin maju dan berkembang. 


\section{Ucapan Terima Kasih}

Pengenalan bisnis kopi kayu manis telah dilaksanakan dengan baik tanpa ada hambatan berarti. Peserta sangat antusias dan bersemangat dalam pelaksanaan kegiatan dari awal hingga akhir. Apresiasi yang setinggi-tingginya disampaikan kepada Mahasiswa Akademi Komunitas Presiden dan jajaran pemangku jabatan di Akademi Komunitas Presiden yang telah memberikan kesempatan untuk mengikuti kegiatan ini (surat terlampir), para Mahasiswa Program Studi Manajemen President University yang namanya tertera pada Tabel 6 yang telah menularkan pengetahuan dan pengalamannya tentang kopi kayu manis dan seluruh tim (lihat lampiran).

Tabel 6.

Daftar Mahasiswa Pelaksana Kegiatan

\begin{tabular}{|c|l|l|l|}
\hline No. & \multicolumn{1}{|c|}{ NIM } & \multicolumn{1}{c|}{ Nama } & \multicolumn{1}{c|}{ Peran } \\
\hline 1 & 014201905051 & Bram Febrian & Koordinator acara \\
\hline 2 & 014201905042 & Daden Sastra & Logistik \\
\hline 3 & 014201905050 & Kelvin Saptona & Marketing Produk \\
\hline 4 & 014201905013 & Risky Hermawan & Pembelian bahan \\
\hline 5 & 014201905043 & Widyawati P. Dewi & Keuangan \\
\hline
\end{tabular}

\section{REFERENSI}

Ferry, Y. (2013). Prospek Pengembangan Kayu Manis (Cinnamomum Burmanii L) di Indonesia. Sirinov, 1(1), 11-20.

Kartika, Y.D., Rifin, A., Saptono, I.T. (2018). Strategi Pengembangan Usaha Pengolahan Kopi Arabika (Studi Kasus PT Golden Malabar). Jurnal Aplikasi Manajemen dan Bisnis, 4(2), 212-219.

Najiyati S. D. (1997). Budidaya Kopi dan Pengolahan Pasca Panen. Jakarta: Penebar Swadaya.

Panggabean, E. (2011a). Mengeruk Untung dari Bisnis Kopi Luwak. Jakarta: Agromedia Pustaka.

Panggabean, E. (2011b). Buku Pintar Kopi. Jakarta: Agromedia Pustaka.

Rahardjo, P. (2012). Kopi Panduan Budidaya dan Pengolahan Kopi Arabika dan Robusta. Jakarta: Penebar Swadaya.

Widiyanto, I., Anandito, B.K., Khasanah, L.U. (2013). Ekstraksi Oleoresin Kayu Manis (Cinnamomum Burmannii): Optimasi Rendemen dan Pengujian Karakteristik Mutu. Jurnal Hasil Teknologi Pertanian, VI(1), 7-15. 


\section{LAMPIRAN}

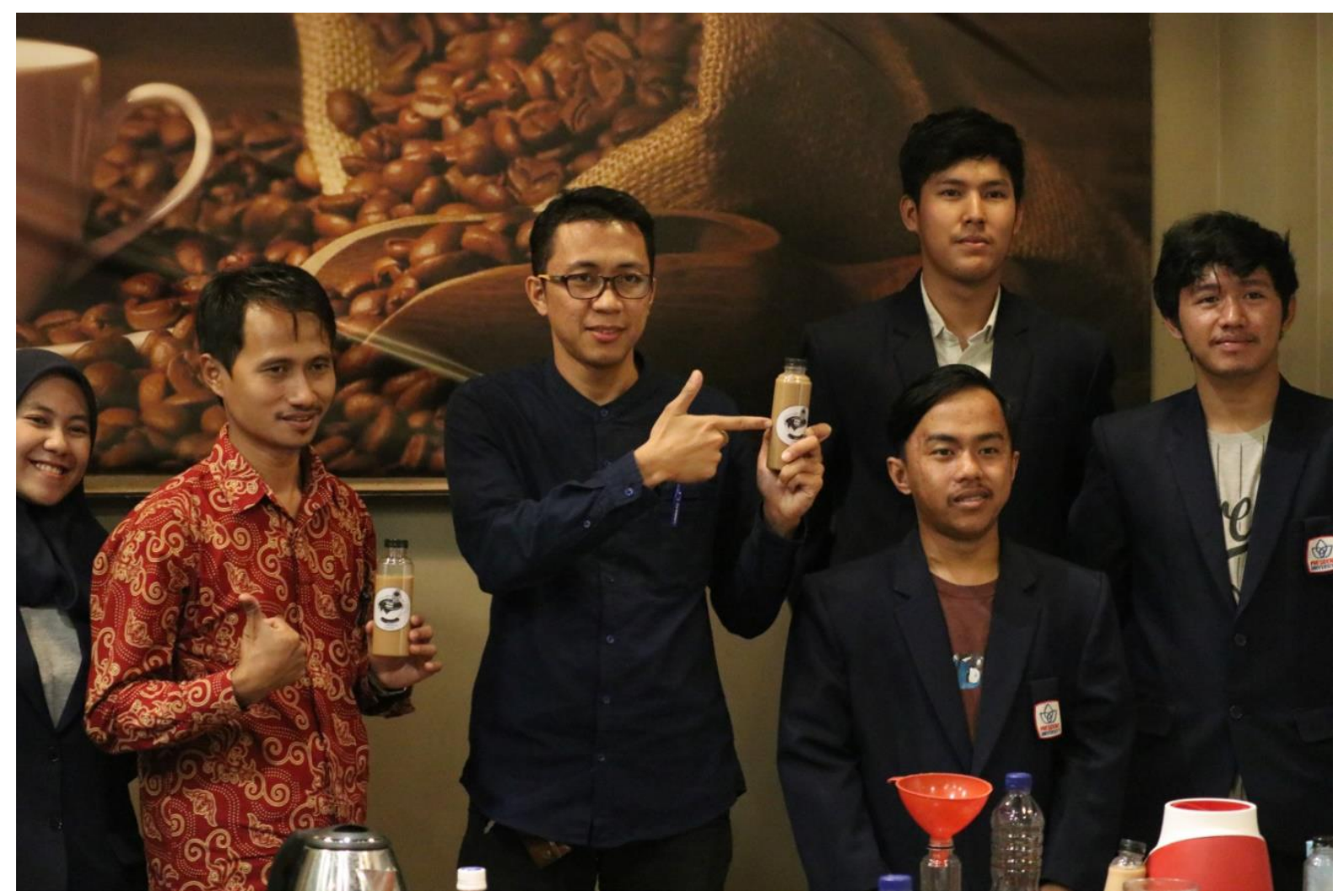

Gambar 6.

Tim PKM Kopi Kayu Manis 


\section{4}

\section{AKADEMI KOMUNITAS PRESIDEN}

\section{SURAT KETERANGAN}

No:065/S.Ket-AKP/XII/2019

Yang bertandatangan dibawah ini :

$\begin{array}{ll}\text { Nama } & \text { : Johan Krisnanto Runtuk, ST., MT. } \\ \text { Tempat, tanggal lahir } & \text { : Wakil Direktur } \\ \text { Alamat } & \text { : Jalan Ki Hajar Dewantara, Kota Jababeka, RT.2/RW.4, } \\ & \text { Mekarmukti, Cikarang Utara, Bekasi, Jawa Barat 17550 }\end{array}$

Dengan ini menyatakan bahwa nama-nama dibawah ini memang benar melakukan Pengenalan Kewirausahaan kepada Mahasiswa Akademi Komunitas Presiden dengan kegiatan cara membuat Es Kopi Susu beserta cara pemasarannya.

Adapun nama-nama tersebut sebagai berikut :

$\begin{array}{ll}\text { Koordinator Kegiatan } & \text { : Bram Febrian } \\ \text { Anggota } & \text { : Kelvin Saptona } \\ & \text { : Risky Hermawan } \\ & \text { : Daden Sastra Pratama } \\ & \text { : Widyawati Puspita Dewi } \\ \text { Dosen Pendamping } & : \text { Abdul Ghofir } \\ & : \text { Genta Sahuri }\end{array}$

Demikian Surat Keterangan ini dibuat dengan sebenarnya untuk dapat dipergunakan sebagaimana mestinya.



Johan Krisnanto Runtuk,-S.T.,M.T. 